\title{
The artificial trachea: A mission of creativity, perspiration, and perseverance
}

\author{
Wayne L. Hofstetter, MD
}

\author{
From the Department of Thoracic and Cardiovascular Surgery, University of Texas MD Anderson Cancer Center, \\ Houston, Tex. \\ Author has nothing to disclose with regard to commercial support. \\ Received for publication May 8, 2018; revisions received May 8, 2018; accepted for publication May 9, 2018; \\ available ahead of print June 19, 2018. \\ Address for reprints: Wayne L. Hofstetter, MD, Department of Thoracic and Cardiovascular Surgery, University \\ of Texas MD Anderson Cancer Center, 1400 Pressler St, Unit 1489, Houston, TX 77030-4009 (E-mail: \\ whofstetter@mdanderson.org). \\ J Thorac Cardiovasc Surg 2018;156:1273-4 \\ $0022-5223 / \$ 36.00$ \\ Copyright (c) 2018 by The American Association for Thoracic Surgery \\ https://doi.org/10.1016/j.jtcvs.2018.05.021
}

\begin{abstract}
"So attracted have surgeons been by the illusory simplicity of developing a conduit to replace native trachea."
\end{abstract}

$$
\text { — Hermes Grillo, } 2002^{1}
$$

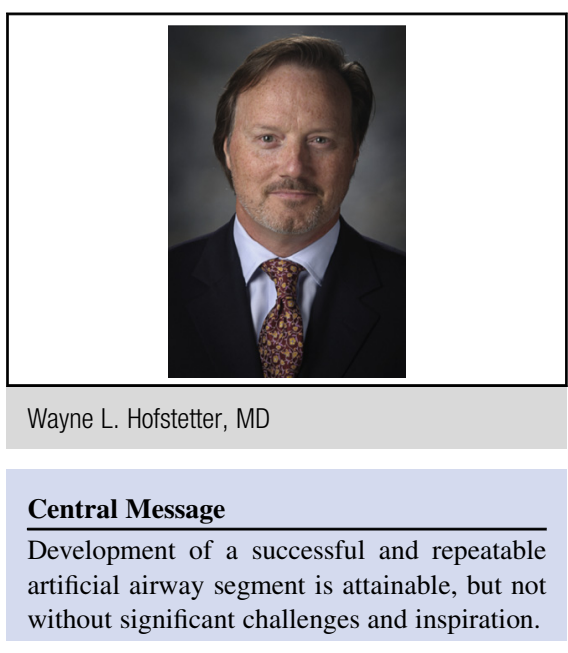

See Article page 1264 .
When I ponder amazing advances in science, I often reflect on the inception of space travel. The Apollo space program was an all-hands-on-deck race to the moon that was launched not long after the Russian artificial Earth satellite, Sputnik 1, streaked like a comet across global skies. That 3month orbital event sparked inspiration and challenged the world's great thinkers to push farther into space and explore the boundaries of technology, creativity, and nerve. Like Sputnik and then later Project Apollo's lunar landing in 1969, circumferential segmental tracheal replacement represents the zenith of tracheal surgery in our time. I will be the first to admit that reading about scientific breakthroughs in tracheal replacement research never fails to induce awe and wonder in me much like what I experience when I read about early experiences with space travel. Yet, despite decades of innovative research in tracheal replacement, ${ }^{2,3}$ we have yet to fully realize our ambition.

What obstacles remain in the path to achieving this goal? First of all, inasmuch as the airway seems like a simple, hollow conduit, it is a uniquely adapted and highly specialized organ that has proven very difficult to replicate. Also, one has to recognize that advancements in surgical techniques have enabled the resection and primary reconstruction of up to half of the adult airway. This revelation altered the landscape of artificial trachea research. Once the knowledge gap in surgical techniques was surmounted, the indications for tracheal replacement became rare, to the point that only the most specialized centers on the planet saw enough volume in these diseases to generate interesting research.

Sakaguchi and colleagues ${ }^{4}$ present a portion of their animal research on an artificial tracheal construct. It is important to

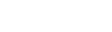


combination of tissue-regeneration methods, tissue transfer, and mechanical engineering. It is only a matter of time before the key combination is unlocked and becomes efficient enough for translation into our operating theaters.

\section{References}

1. Grillo HC. Tracheal replacement: a critical review. Ann Thorac Surg. 2002;73: 1995-2004.
2. Daniel RA. The regeneration of defects of the trachea and bronchi; an experimental study. J Thorac Surg. 1948;17:335-49.

3. Aronstam EV, Nims RM, Winn DF Jr. Studies in segmental replacement of the thoracic trachea. J Surg Res. 1961;1:108-10.

4. Sakaguchi Y, Sato T, Muranishi Y, Yutaka Y, Komatsu T, Omori K, et al. Development of a novel tissue-engineered nitinol-frame artificial trachea with native-like physical characteristics. J Thorac Cardiovasc Surg. 2018; 156:1264-72.

5. Wykoff TW. A preliminary report on segmental tracheal prosthetic replacement in dogs. Laryngoscope. 1973;83:1072-7. 